\title{
EVALUATION OF THE PHYTOTOXICITY OF COTTON MICRODUST COMPOST BASED ON SEED GERMINATION AND SEEDLING GROWTH
}

\author{
E. PREETHA ${ }^{\mathbf{1}}$ \& P. SARAVANAKUMARI ${ }^{2}$ \\ ${ }^{1}$ Research Scholar, Research and Development Centre, Bharathiar University, Coimbatore, Tamil Nadu, India \\ ${ }^{2}$ Assistant Professor, Department of Microbiology, Sree Narayana Guru College, Coimbatore, Tamil Nadu, India
}

\begin{abstract}
This paper focuses on the experiment, to evaluate the phytotoxicity of five different composts obtained, by mixing inhalable cotton micro-dust, sugar cane bagasse and saw-dust in 1:1:1, 2:1:1, 3:1:1, 4:1:1 and 5:1:1 ratios and composted for 45days. An experiment was carried out, to evaluate the affected of seed germination and seedling growth of Trigonella foenum, Phaseolus vulgaris and Vigna radiate, by aqueous extracts of compost. After incubation, germinated seeds were numbered $(G)$ and root growth $(L)$ was measured. Germination index $(G I)$ was calculated: $(G I)=G / G(x) / L_{0} x 100$, and values obtained using distilled water (control). Higher germination index, average root and shoot length was observed in compost Trail 3, prepared from substrate mixing in ratio of 3:1:1. Germination Index \% of all trails were above $64 \%$ and Trail 3 exhibited the highest GI\% in 126 for Trigonella foenum seedling, 137 for Phaseolus vulgaris seedling and 101 for Vigna radiate seedling hence, were selected as best compost.

KEYWORDS: Cotton Micro-Dust, Sugarcane Bagasse, Saw-Dust, Germination Index, Phytotoxicity \& Physicochemical
\end{abstract}

Received: Sep 01, 2017; Accepted: Sep 21, 2017; Published: Sep 28, 2017; Paper Id.: IJASROCT201746

\section{INTRODUCTION}

Phytotoxicity is one of the most important measures, to estimate the appropriateness of compost for agricultural function and to avoid environmental risks, before these composts can be used to agricultural field (Tiquia et al., 1996; Brewer and Sullivan, 2003, Cooperband et al., 2003, Adegunloye, 2009 \& Farhan et al., 2010). Many research works have reported that, using of immature compost into the soil causes negative effects on germination and growth development of the farm (Christian et al., 1997). This side effect is because, the immature compost contain high microbial load, which reduce the concentration of oxygen in the soil and blocks the available nitrogen for plant uptake (Tiquia, 2003, Tuomela et al., 2000, Zucconi et al., 1981). Immature composts also containing compounds, such as heavy metals which are toxic to plant growth (Brewer, 2003, Tam and Tiquia, 1994, morel et al., 1985, Mathur et al., 1993 \& Maggie et al., 1967). Moreover, the presence of phenolic and ethylene compounds, ammonia, organic acids, and excess salts could retard seed germination and plant growth. Organic acid like Acetic acid is the most damaging acid, present in immature compost that mainly causes a phytotoxic effect (Ozores-Hampton, 1998). Application of no stabilized organic materials, will affect both the crops and environment (Bashan \& Dubrovsky, 1996, Butler et al., 2001). Phytotoxicity of compost is often evaluated, by seed germination or growth tests (Gariglio et al., 2002 \& Brewer and Sullivan, 2003), as presence of high concentrations of salt and the release of organic acids, is correlated with inhibition of seed germination and seed growth (Buswell, 1984).

The maturity of the compost can be studied by the germination index method, which is based on seed 
germination and initial plant growth (Butler et al., 2001, Cambardella et al., 2003 \& Carr 1995). This is done by using a liquid extract from the prepared compost. The compost is measured to be mature, when the germination index is higher than $60 \%$ (Gajdos, 1997, Gariglio et al., 2002 \& Georgacakis et al., 1996). In general, the compost is non-toxic, when the germination rate is more than 85\% (Abdul et al., 2013, Cheung and et al., 1989). Composting is a practical approach for the sustainable reprocess of organic wastes (Finstein and miller, 1985, Tuomela et al., 2000). Composting is a biological course of action, through which microbes alter organic materials into functional end products, which may be used as soil conditioners and/or organic fertilizers (Forstet et al, 1993).

The particulate yield of composting, are extracted during the maturation and curing phase are called as compost. Composting has become a favored technique for municipalities and industries, to recycle a diversity of organic derivative into a safer and more stable material, for application to the soil (Butler et al., 2001; Carr et al., 1995). The waste material used for the composting varies in their nutrient and mineral substance, as this concern the rate of breakdown and the composition of developing compost (Adegunloye et al., 2009).

\section{MATERIALS AND METHODS}

\section{Sample Collection}

Various composts were prepared using a combination of substrates; these substrates included sugar cane bagasse, saw dust, and blow room cotton micro dust from the textile industry. The effective microorganism solution was purchased from Environ Biotech.

\section{Sample Preparation}

Approximately, 30- $31 \mathrm{Kg}$ of substrate mixtures were prepared separately by mixing cotton micro dust, sugar cane bagasse and saw dust in 1:1:1, 2:1:1, 3:1:1, 4:1:1 and 5:1:1 ratios, respectively. Combinations of these substrates were properly mixed on a concrete platform with watering, to bring the final moisture in the range of 50- 62\%. All the test composts were run in triplicate and the results were shown, with the average of three replicates.

\section{Sample Extraction}

A water extract of compost were prepared, by shaking the samples with distilled water at 1:10 w/v ratio for 3 hours, and then filtered by filter paper.

\section{Seed Germination Experiment}

The seeds of Trigonella foenum, Phaseolus vulgaris and Vigna radiate used in the study were first surfacesterilized with $0.1 \%$ mercuric chloride solution for $20 \mathrm{~min}$, and washed properly with distilled water before germination to ensure viability. Thirty seeds of Trigonella foenum, Phaseolus vulgaris and Vigna radiate were placed in $9.5 \mathrm{~cm}$ Petri plates, lined with a double layer of Whatman No. 1 filter paper. Each plate was moistened with $5 \mathrm{ml}$ of the respective extract concentrations. One plate is kept as a control, using distilled water. The Petri dishes were firmly sealed with parafilm and incubated for 6 days (124 hours) at $27 \pm 2{ }^{\circ} \mathrm{C}$ in a growth chamber (16 h light and $8 \mathrm{~h}$ dark). The initial seed germination count was done after $24 \mathrm{~h}$ of incubation, to determine percentage germination and/or inhibition. At the end of the 6-day growth was assessed, based on the lengths of plumule and radical relative to the control. Germination index (GI) was calculated: $(\mathrm{GI})=\mathrm{G} / \mathrm{G}_{0} \times \mathrm{L} / \mathrm{L}_{0} \mathrm{x} 100$, where $\left(\mathrm{G}_{0}\right)=$ No of seeds germinated in compost extract / No of seed germinated in control X 100 and $\left(\mathrm{L}_{0)}=\right.$ mean root length in composts extract / mean root length in control X 100. 


\section{Physicochemical Study of Selected Compost}

The $\mathrm{pH}$ was determined on a suspension of sample in water $(10 \mathrm{~g} / 25 \mathrm{ml})$, the total nitrogen (Kjeldahl method). Phosphorus availability was determined by titration method, using quinoline and $\mathrm{HCl}$. Phenolphthalein act as indicator. Organic matter present in the composite is also determined by the titration method.

\section{RESULTS}

GI is mainly considered as a sensitive parameter, for identifying the phytotoxity of compost. The suitability of compost for use as soil amendment, has also been calculated from these results. Many authors report that, root length contributes much to the results than shoot, as they are more sensitive to the toxins during germination, but it's a combination of relative germination and relative root elongation. (Emino et al., 2004) Root and shoot lengths of $124 \mathrm{hr}$ old three different seedlings (Trigonella foenum, Phaseolus vulgaris and Vigna radiate) in aqueous extracts of different substrates, are presented in Tables 1. The longest roots were observed in Trail 3, for Trigonella foenum and Phaseolus vulgaris i.e. $24.0 \mathrm{~mm}$ and $24.3 \mathrm{~mm}$, respectively and Trail 2 for Vigna radiate. Meanwhile, extract of Trail 5 had an adverse effect on root length of all three seedlings i.e. $10.5 \mathrm{~mm}, 10.9 \mathrm{~mm}$ and $6.6 \mathrm{~mm}$, respectively. The longest roots were observed in Trail 4, for Trigonella foenum Phaseolus vulgaris i.e. $37.0 \mathrm{~mm}, 37.3 \mathrm{~mm}$, respectively and Trail 3 for Vigna radiate. Germination index was also calculated and given in table 2 . While, observing GI \%, out of five trails on substrate combination, three combinations showed $>100$ value on Trigonella foenum seeds, two combination showed $>100$ value on Phaseolus vulgaris seeds and three combinations showed $>100$ value, on Vigna radiate seeds.

Table1: Seed Germination and Seedling Growth

\begin{tabular}{|c|c|c|c|c|c|c|}
\hline \multirow{2}{*}{ Samples } & \multicolumn{2}{|c|}{ Trigonella foenum } & \multicolumn{2}{c|}{ Phaseolus vulgaris } & \multicolumn{2}{c|}{ Vigna Radiate } \\
\cline { 2 - 7 } & $\begin{array}{c}\text { Average } \\
\text { Root Length } \\
(\mathbf{c m})\end{array}$ & $\begin{array}{c}\text { Average } \\
\text { Shoot } \\
\text { Length } \mathbf{( c m )}\end{array}$ & $\begin{array}{c}\text { Average } \\
\text { Root Length } \\
(\mathbf{c m})\end{array}$ & $\begin{array}{c}\text { Average } \\
\text { Shoot } \\
\text { Length }(\mathbf{c m})\end{array}$ & $\begin{array}{c}\text { Average Root } \\
\text { Length }(\mathbf{c m})\end{array}$ & $\begin{array}{c}\text { Average } \\
\text { Shoot Length } \\
(\mathbf{c m})\end{array}$ \\
\hline Control & $17.7 \pm 0.624$ & $3.7 \pm 0.624$ & $18.0 \pm 0.153$ & $3.8 \pm 0.513$ & $16.4 \pm 0.451$ & $2.7 \pm 0.513$ \\
\hline Trail 1 (1:1:1) & $16.3 \pm 0.611$ & $2.7 \pm 0.557$ & $16.5 \pm 0.306$ & $2.7 \pm 0.603$ & $14.1 \pm 0.100$ & $2.9 \pm 0.551$ \\
\hline Trail 2 (2:1:1) & $14.2 \pm 0.058$ & $3.0 \pm 0.666$ & $14.3 \pm 0.321$ & $3.1 \pm 0.764$ & $24.3 \pm 0.577$ & $2.4 \pm 0.436$ \\
\hline Trail 3 (3:1:1) & $24.0 \pm 0.000$ & $2.6 \pm 0.872$ & $24.3 \pm 0.577$ & $2.6 \pm 1.012$ & $19.8 \pm 0.681$ & $3.6 \pm 0.513$ \\
\hline Trail 4 (4:1:1) & $19.5 \pm 0.500$ & $3.7 \pm 0.808$ & $19.9 \pm 0.854$ & $3.7 \pm 0.874$ & $10.7 \pm 1.955$ & $4.9 \pm 0.551$ \\
\hline Trail 5 (5:1:1) & $10.5 \pm 1.572$ & $4.7 \pm 1.044$ & $10.9 \pm 2.178$ & $4.9 \pm 1.210$ & $6.6 \pm 0.764$ & $4.0 \pm 0.436$ \\
\hline
\end{tabular}

Table 2: Germination Index of Trails

\begin{tabular}{|l|l|c|c|c|}
\hline & Compost Samples & Trigonella Foenum & Phaseolus Vulgaris & Vigna Radiate \\
\hline \multirow{4}{*}{$\begin{array}{l}\text { Germination } \\
\text { Index \% }\end{array}$} & Trail 1 (1:1:1) & 64 & 80 & 101 \\
\cline { 2 - 5 } & Trail 2 (2:1:1) & 123 & 115 & 90 \\
\cline { 2 - 5 } & Trail 3 (3:1:1) & 126 & 137 & 101 \\
\cline { 2 - 5 } & Trail 4 (4:1:1) & 105 & 99 & 86 \\
\cline { 2 - 5 } & Trail 5 (5:1:1) & 92 & 91 & 156 \\
\hline
\end{tabular}

All the parameters studied for selected compost (trail 3) in the work were studied, and the results are within specification by the Environmental Protection Agency, in accordance with Waste Licensing under the Waste Management Act 1996. The recommended range of moisture content was specified in Biotreat, 2003, and other constituents such as particle density, $\mathrm{pH}$, conductivity, bulk density, available ammonia nitrogen, nitrate nitrogen, total phosphorus and potassium of compost in article of Bord na Mona, 2003 whereas, Limit for organic matter and C:N ratio calcium, magnesium and total nitrogen in compost as per Barker, 1997. The moisture content was $60 \%$. Particle size of compost 
was $0.21456 . \mathrm{pH}$ at $25^{\circ} \mathrm{C}$ (1\% Suspension) was 6.10. The electrical conductivity ( $1 \%$ Suspension) of compost is 4.58 $\mathrm{ds} / \mathrm{m}$. The total nitrogen as $\mathrm{N}$ of the compost was $1.02 \%$. The phosphorous as $\mathrm{P}$ concentration was $698.84 \mathrm{mg} / \mathrm{kg}$. Potassium as $\mathrm{K}$ concentration was $0.89 \%$. Organic matter content of the compost was $15.80 \%$. Magnesium as $\mathrm{Mg}$ concentration was $48.99 \mathrm{mg} / \mathrm{kg}$. The sodium concentration was $0.023 \%$. The $\mathrm{C} / \mathrm{N}$ ratio of all the compost was $18.1 \%$. The nitrate-nitrogen concentration varied from $145.8 \mathrm{mg} / \mathrm{L}$.

\section{DISCUSSIONS}

According to the obtained results of germination index, extract prepared for trail 3 (3:1:1) seems to be safer and clearly confirms that, complete composting reduce phytotoxicity, this was earlier proved in the results of Delgado et al., 2010. Trail 3 (3:1:1) showed highest GI \% on all three seeds and Trail 1 (1:1:1) showed minimum GI \%. Results of Zucconi, 1985, indicated that, the GI value below $50 \%$ indicates high phytotoxicity and $80 \%$ indicates no toxicity and when Index exceeds $100 \%$ the compost is considered to be very good phytonutrient or phytostimulant, for the respective seedlings. Also, Ogbo et al., 2010, Morel et al., 1985, Mathur 1993, observed in their works that, root length were higher in maturing composts. Meanwhile, the $\mathrm{pH}$ value of selected compost was 6.10 , which is $\mathrm{pH}$ raises, due to the organic acids breakdown, during the composting process that occurs during the decomposition, organic acid volatilization and discharge

of ammonia by microbes, as they break down proteins and other organic nitrogen sources. The pH becomes neutral, as the ammonia is either evaporated or utilized by new microbial colony. Decreasing particle size will encourage microbial activity and clearly denote the rate of decomposition. The availability of carbon and nitrogen is increased in compost, by decreasing particle size. Fang and Wong, 1999 found a relationship between GI and C: N ratio and reported that, compost with good GI have soluble Carbon and Nitrogen for plant uptake. GI increases in supply of oxygen and indirectly proves that, compost was prepared by and matured under adequate temperature, oxygen, humidity and nutrient concentration. Wong et al., 1983 and 1985, studied on various extracts of the same compost, at different percentages and noted that, GI percentage varies. Gariglio et al., 2002 also concluded that GI did not increase at various compost extract, due to saw dust on Salix sp.

\section{CONCLUSIONS}

Upcoming textile industries face great problems in waste management. Inhalable cotton dust wastes were selected, as the main raw material for composting as South India is rich in textile industry. As agriculture is the backbone of India, this research can give an economically viable product for farmers with cheap rate and high yield, without much soil and water pollution. The paper elaborates the phytotoxicity study of prepared compost, which gives improved quality of crops in agriculture. Germination study was also done, and results for parameters such as germination percentage, root length, shoot length, etc., and clearly denoted that, it can be used as biomanure without any restriction.

\section{REFERENCE}

1. Abdul, H., M.Z. Ahmed, S. Gulzar, B.G.J. Alam, A.K. Hegazy, A.R. Alatar and M.A. Khan. (2013). Seed germination and recovery response of Suaeda Heterophylla to abiotic stresses. Pak. J. Bot. 45(5): 1649-1656.

2. Adegunloye, D.V. and F.C. Adetuyi. (2009). Composting of food wastes using cow and pig dung as booster. Afr. J. Basic Appl. Sci. 1(3-4): 70-75.

3. Bashan, Y. and G. Dubrovsky. (1996). Azospirillum spp. participation in dry matter partitioning in grasses at the whole plant level. Biol. Fertil. Soils. 23: 435-440. 
4. Barker, A.V. (1997). Composition and uses of compost, agricultural uses of by-products and wastes, ASC Symposium series. American Chemical Society, 668 (10): 140-162.

5. Bernal, M.P., M.A. Paredes, M.A. Sanchez-Monedero and J. Cegarra. (1998). Maturity and stability parameters of composts prepared with a wide range of organic wastes. Bioresour. Technol. 63: 91-99.

6. Brewer, L.J. and D.M. Sullivan. (2003). Maturity and stability evaluation of composted yard trimmings. Compost Sci. Util. 11(2): 96-112.

7. Biotreat. (2003). Interpretation of results report, National Food Biotechnological Centre, University College, Cork, Ireland.

8. Bord na Mona. (2003). Compost testing and analysis Service - interpretation of results, available from Bord na Mona, Newbridge, Co. Kildare.

9. Buswell, J.A. (1984). Potentials of spent mushroom substrates for bioremediation purposes. Compost Sci. Util. 2(3): 31-35.

10. Butler, T.A., L.J. Sikora, P.M. Steinhilber and L.W. Douglass.(2001). Compost age and sample storage effects on maturity indicators of biosolids compost. J. Environ. Qual. 30: 2141-2148.

11. Cambardella, C.A., T.L. Richard and A. Russell. (2003). Compost mineralization in soil as a function of composting process conditions. Eur. J. Soil Biol. 39: 117-127.

12. Carr, L., R. Grover, B. Smith, T. Richard and T. Halbach. (1995). Commercial and on-farm production and marketing of animal waste compost products. K. Steele (Ed.). Animal waste and the land water interface. Lewis Publishers, Boca Raton. p. 485-492

13. Cheung, Y.H., M.H. Wong and N.F.Y. Tam. (1989). Root and shoot elongation as an assessment of heavy metal toxicity and 'Zn equivalent value' of edible crops. Hydrobiologia. 188: 377-383.

14. Christian, A.H, G.K. Evanylo and J.W. Pease. (1997). On farm composting: A guide to principles, planning and operations. Virginia Cooperative Extension. Blacksburg, Virginia.

15. Cooperband, L.R., A.G. Stone, M.R. Fryda and J.L. Ravet. (2003). Relating compost measures of stability and maturity to plant growth. Compost Sci. Util. 11: 113-124.

16. Delgado, M.M., J.V. Martin, R. Miralles, C. Leon-Cofreces and M.C. Garcia. (2010). Phytotoxicity of uncomposted and composted poultry manure. Afr. J. Plant Sci. 4(5): 154-162.

17. Emino, E.R. and P.R. Warman. (2004). Biological assay for compost quality. Compost Sci. Util. 12(4): 342-348.

18. Erhart, E. and K. Burian. (1997). Evaluating quality and suppressiveness of Austrian biowaste composts. Compost Sci. Util. 5(3): $15-24$.

19. Fang, M. and J.W. Wong. (1999). Effects of lime amendment on availability of heavy metals and maturation in sewage sludge composting. Environ. Pollut. 106: 83-89.

20. Farhan, Z., S. Meghashiri, S. Gopal and B.R. Rao. (2010). Chemical and microbiological dynamics during composting of herbal pharmaceutical industrial waste. E- J. Chem. 7(1): 143-148.

21. Finstein M.S. and F.C. Miller. (1985). Composting of Agricultural and other Wastes. Elsevier Applied Science, Barking UK.

22. Forster J.C., W. Zech and E. Würdinger. (1993). Comparison of chemical and microbiological methods for the characterization of the maturity of composts from contrasting sources. Biol. Fertil. Soils. 16(2): 93-99.

23. Gajdos, R. (1997). Effects of two composts and seven commercial cultivation media on germination and yield. Compost Sci. Util. 5: 16-37. 
24. Gariglio, N.F., M.A. Buyatti, R.A. Pilatti, D.E.G. Rossia and M.R. Acosta. (2002). Use of a germination bioassay to test compost maturity of willow (Salix sp.) sawdust. New Zeal. J. Crop Hort. Sci. 30: 135-139.

25. Georgacakis, D., A. Tsadaris, J. Bakouli and S. Symeonidis. (1996). Composting of solid swine manure and lignite mixture with selected plant residues. Bioresour. Technol. 56: 195-200.

26. Mathur, S.P., G. Owen, H. Dinel and M. Schnitzer. (1993). Determination of compost biomaturity. Biol. Agric. Hortic. 10: 6585 .

27. Meggie, C.A., R.W. Pearson and A.E. Hilthold. (1967). Toxicity of decomposing crop residues to cotton germination and seedling growth. Agron. J. 59: 197-199.

28. Morel, J.L, F. Colin, J.C. Germon, P. Godin and C. Juste. (1985). Methods for the evaluation of the maturity of municipal refuse compost. In: J.K.R. Gasser (ed.). Composting of agricultural and other wastes. Elsevier Applied Science, New York, USA.

29. Ogbo, E.M., A. Tabuanu and R. Ubebe. (2010). Phytotoxicity assay of diesel fuel-spiked substrates remediated with Pleurotus tuberregium using Zea mays. Int. J. Appl. Res. Nat. Prod. 3(2): 12-16.

30. Ozores-Hampton, M. (1998). Compost as an alternative weeds control method. Horti. Sci. 33(6): 938-940.

31. Tam, N.F.Y. and S.M. Tiquia. (1994). Assessing toxicity of spent sawdust pig litter using seed germination technique. Resour. Conserv. Recycl. 11: 261-274.

32. Tiquia, S.M. (2003). Evaluation of organic matter and nutrient composition of partially decomposed and composted spent pig litter. Environ. Technol. 24: 97-107.

33. Tuomela, M., M. Vikman, A. Hatakka and M. Itavaara. (2000). Biodegradation of lignin in a compost environment: A review. Bioresour. Technol. 72: 169-183.

34. Warman, P.R. (1999). Evaluation of seed germination and growth test for assessing compost maturity. Compost Sci. Util. 7: $33-37$.

35. Wong, M.H. (1985). Phytotoxicity of refuse compost during the process of maturation. Environ. Pollut. 37: 159-174.

36. Wong, M.H., Y.H. Cheung and C.L. Cheung. (1983). The effect of ammonia and ethylene oxides in animal manure and sewage sludge on seed germination and root elongation of Brassica parachinensis. Environ. Pollut. 30: 109-123.

37. Zucconi, F., A. Monaco and M. Forte. (1985). Phytotoxins during the stabilization of organic matter. In: Gasser J.K.R. (ed.). Composting of agricultural and other wastes. Elsevier Applied Science Publication, New York, U.S.A. p. 73- 86. 